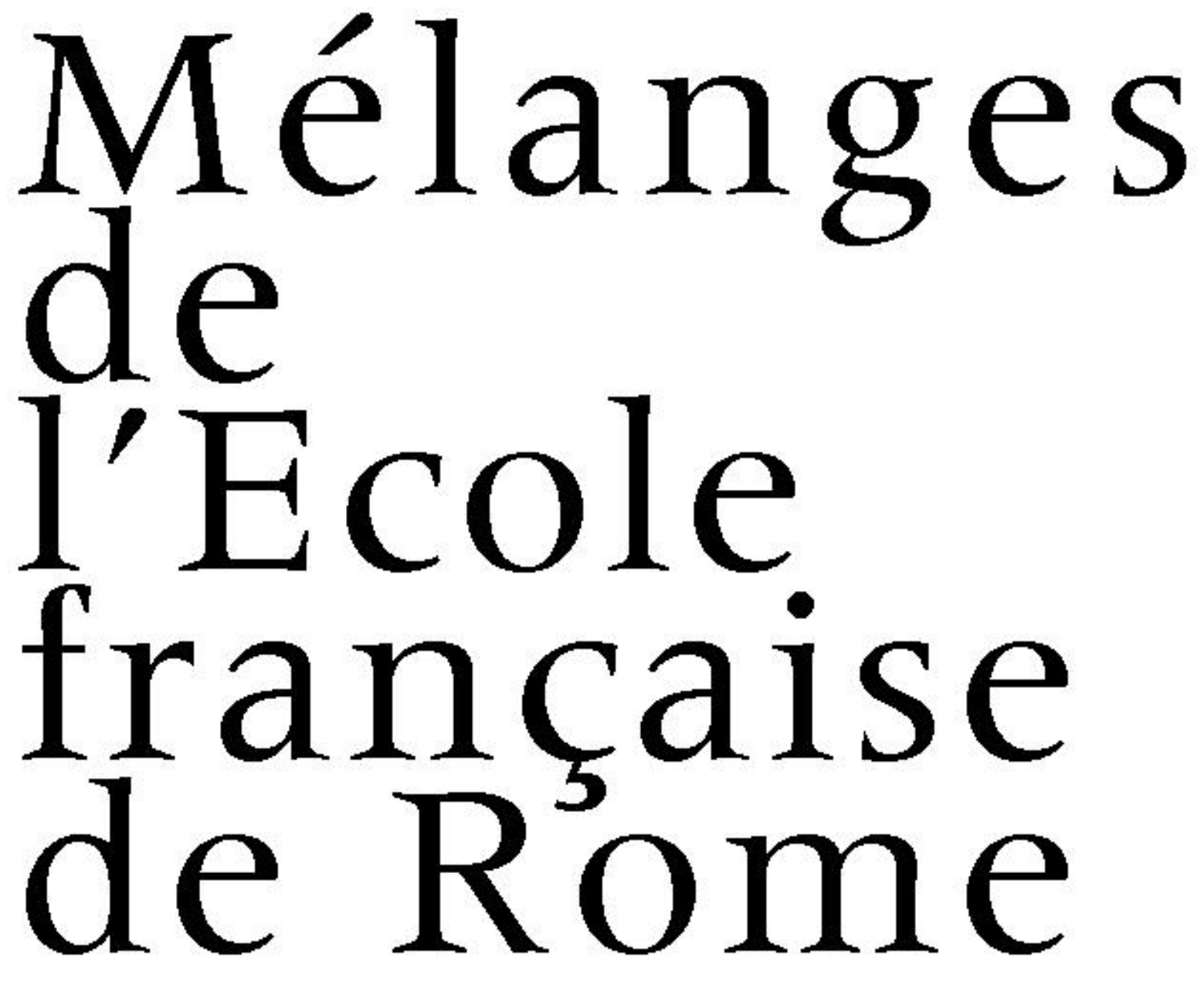

Moyen Âge

MEFRM

130-1 2018 


\section{CATALOG UE}

[Périodique] , Moyen Âge

Mélanges de l'École française de Rome. Moyen Âge 130/1 (2018)

Mélanges de l'École française de Rome

Roma: École française de Rome, 2018

ISBN: 978-2-7283-1350-1

ISSN: $1123-9883$

264 p., ill. $n / b$ et coul.

Version en ligne TORROSSA Version en ligne journals.openedition.org

État: Disponible

Prix: $€ 50$ 舞

L'Armenia nel Medioevo, vettore di mobilità tra Oriente e Occidente (sec. XII-XV

Introduzione, par Irene Bueno, Federico Alpi et Anna Sirinian ; La Chiesa armena e Roma nella Storia di Tamerlano di Tovma Mecop'ec'i, par Marco Bais Immagini degli Armeni nelle fonti arabe di età mamelucca. Il caso Mufaḍdal, par Giuseppe Cecere ; Les Arméniens, la * nation » préférée des Latins partis pour la Terre sainte entre XII et XIII siècles ?, par Camille Rouxpetel ; Dalla guerra alle meraviglie orientali. Le letture della Flor des estoires de la terre d'Orient nel Medioevo, par Irene Bueno ; In Magna Armenia: appunti sugli Armeni nella Caffa del XIV secolo, par Federico Alpi ; Gli Armeni in Italia, ed in particolare in Toscana, nel Medioevo ed oltre, par Alessandro Orengo ; Interazioni armeno-latine nelle epigrafi e nei manoscritti armeni prodotti a Roma nei secoli XIII-XIV, par Anna Sirinian.

Beyond their dowries. Women and wealth in medieval and early modern north-central Italy

Looking beyond their dowries, par Denise Bezzina ; Married women, law and wealth in 14th-century Genoa, par Denise Bezzina ; Women and wealth in late

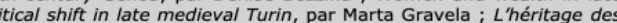
列 Jewish women in the ghettos of north-central Italy (17th-18th centuries), par Michaël gASperoni ; Multe sunt mulieres in matrimonio existentes que habent bona propria. Réflexions conclusives sur le dossier \& Beyond their dowries", par Isabelle Chabot.

Varia

Dipingere il marmo nella Langobardia. La sintassi ornamentale da ponte con la tarda Antichità a matrice di una cultura artistica, par Fabio Scirea.

Milano, gli irlandesi e l'ímpero carolingio nel IX secolo. Intrecci politici e culturali intorno al divorzio di Lotario II, par Miriam Rita Tessera.

\section{Pour citer cet article}

Référence papier

Denise Bezzina, « Looking beyond their dowries », Mélanges de I'École française de

Rome - Moyen Âge, 130-1 | -1, 113-119.

Référence électronique

Denise Bezzina, « Looking beyond their dowries », Mélanges de l'École française de Rome - Moyen Âge [En ligne], 130-1 | 2018, mis en ligne le 05 novembre 2018, consulté le 25 juin 2020. URL : http://journals.openedition.org/mefrm/4041; DOI : https://doi.org/10.4000/mefrm.4041

\section{Auteur}

Denise Bezzina

Notariorum Itinera - University of Genoa, denisebezzina@hotmail.com

Articles du même auteur

Married women, law and wealth in 14th-century Genoa [Texte intégral]

Paru dans Mélanges de l'École française de Rome - Moyen Âge, 130-1 | 2018

\section{Droits d'auteur}

(c) École française de Rome 


\title{
Looking beyond their dowries
}

\author{
Denise Bezzina*
}

D. Bezzina, Notariorum Itinera - University of Genoa, denisebezzina@hotmail.com

«Perhaps we should look elsewhere, beyond dowries", this comment made by Christiane Klapisch-Zuber in her The Griselda Complex almost forty years ago encapsulates the scope of the studies collected here. "Yet historians" the scholar went on, "once they had concluded that the dowry played a predominant part in marriage law, lost interest in the assignments based on custom, which are mentioned in a great many documents, although in less than clear terms». ${ }^{1}$

Scholars have all too much used dowries as a barometer of female wealth and agency (or lack thereof). We cannot deny that in pre-modern times dowries constituted the main fund which a woman had right to, certainly, but since law prohibited women from administering their dotal fund until their husband's predecease, marital assigns provide a very partial (if at all) picture of the role of women as proprietors and managers of assets. Moreover, dowries have been the focus multiple studies ${ }^{2}$ which have traced a cogent picture of this portion of female wealth. Female property that was extraneous to the dotal fund and, more in general, female ownership and property rights, have been far less explored, especially for what concerns medieval and early modern northern and central Italy.

In the above-cited excerpt, Klapisch-Zuber was referring to those accoutrements associated with the trousseau, or other marital gifts, which were generally bestowed upon brides. But over and above these often ostentatious and highly symbolic goods, female property could comprise an array of other assets: immovables, cash, income from a daily job or a commercial investment, for example, which a woman could bring with her into her husband's household or else acquire during marriage. As opposed to the dowry, by virtue of the ius commune (Roman civil law), these goods - which jurisprudence labelled bona non dotalia or paraferna - were supposed to remain under a woman's control during marriage. A woman could
* The studies collected here were discussed during a panel entitled Oltre la dote presented at the VII Congress of the Società Italiana delle Storiche which was held in Pisa in February 2017. We resumed our discussion during a seminar on Donne e patrimoni tra medioevo ed età moderna: diritti, modalità di gestione, rapporti familiari, held at the University of Genoa in July of the same year. My colleagues and I would like to express our gratitude to the Società Italiana delle Storiche for providing a venue for discussion, and to the anonymous peer reviewers for their helpful comments. Warmest thanks also to Marina Girona Berenguer who participated in both events with papers on dowry restoration, and non-dotal assets within the Jewish group in late 15th-century Castille.

1. Klapisch-Zuber 1985, p. 217.

2. Apart from the abovementioned study by Klapisch-Zuber, scholarship on dowries is extensive, it is therefore impossible to provide an exhaustive list of titles here. I will only mention a few bibliographical references that cover the issue from different angles. On the early middle ages, see the studies collected in Bougard - Feller - Le Jan 2002. In general on north-central Italy in the late middle ages and early modern period, see Lanaro - Varanini 2009. For what concerns specific cities in northern and central Italy: on Genoa from a legal perspective, see Braccia 2001, on Siena, see Giuliodori 2005, on Florence, see Kirshner Molho 1978, on Rome, see Di Carpegna Falconieri 1995 and Esposito 2013. For a much needed comparison between northern and southern Italy during the middle ages, see Chabot forthcoming. For what concerns the early modern period, for example, on 18th-century Turin see Zucca Micheletto 2011, on the Jewish group see Allegra 1993 and Gasperoni 2015. 
even decide to confer her non-dotal property upon her husband if she wished, but Roman civil law established that he was supposed to restore his wife's property if she reclaimed it. ${ }^{3}$ At least in principle, therefore, women who owned a sizeable estate could exert substantial agency within their households and in society in general.

Yet, non-dotal goods are elusive and difficult to identify in the sources and consequently the topic has hardly ever been considered by scholars. For what concerns the middle ages, so far the only study which addresses specifically goods beyond the dowry remains Julius Kirshner's pioneering Materials for a gilded cage: nondotal assets in Florence, 1300-1500, first published in 1991. ${ }^{4}$ As Kirshner has rightly observed, the problem is also terminological in nature: while dotal goods are always clearly labelled in sources, direct references to non-dotal assets are hard to come by. But the issue remains tangible, since historians tend to ignore the legal nature of non-dotal donations and bequests married women typically received, the degree of wealth they could accumulate beyond their dowries, and who retained the right to administer these funds. In other words, we cannot simply assume that property rights of married women were limited to just their dowries.

Through a cross-analysis of statutes, consilia (legal advice provided by jurists), and other sources (notarial records, Monte credits, ricordanze, petitions) Kirshner has defined the norms and practices surrounding these goods in a context - Florence - where the management of these assets was essentially regulated by municipal legislation. In essence, Kirshner affirms, in Florence by the late middle ages control over non-dotal property was transferred to husbands, and this not only by virtue of a norm introduced in an early 14th-century redaction of the Florentine statutes. ${ }^{5}$

3. The prescriptions of the ius commune on non-dotal goods and differences between bona non dotalia and paraferna are discussed with more detail in Kirshner 2015, p. 75-77; Bellomo 1961, p. $131 \mathrm{ff}$.

4. Kirshner 2015. Another study on Genoa in the period spanning the mid-12th to the 13th centuries is currently in the press, Bezzina forthcoming.

5. Specifically, a norm in the 1325 redaction of the Florentine statutes which stated that husbands could use and manage property that their wives acquired during marriage, Kirshner 2015, p. 81.
This tendency to give full control over female wealth to husbands is also evident in practice. Jurists and legal experts aside, most contemporaries - at times even notaries - ignored the legal difference between dotal and non-dotal assets. To them, these additional portions of wealth which were conveyed to married women as gifts or as a part of an inheritance, were simply supplements to dowries which were aimed at providing widows with sufficient income to live comfortably, and certainly not a means to grant married women a degree of autonomy. To use the scholar's own words: «non-dotal assets were just more materials for the construction of the Florentine wife's gilded cage». ${ }^{6}$

But how far was this tendency echoed elsewhere? Kirshner has charted a cogent and feasible framework for future research on the issue, which should be extended to other less-studied contexts. As the scholar has pointed out, in-depth research in the archives of other Italian cities could determine the extent to which women were likely to receive non-dotal assets, how this portion of female wealth could contribute to the economy of households, as well as the factors which incited relatives to bequeath or donate non-dotal goods to females, thus providing us with a more wellrounded picture of female property rights. ${ }^{7}$

Scholarly literature on the specific topic is still in want also for what concerns the early modern period. ${ }^{8}$ In her noteworthy Pesci Fuor d'acqua, which focuses on the Roman context in early modern times, Simona Feci has addressed the problem of the relationship between possession and management of female wealth effectively, by questioning to what extent women could administer autonomously the non-dotal wealth they accumulated, further delving into the specific

6. Kirshner 2015, p. 93.

7. Ibid., p. 92.

8. Renata Ago has addressed the specific issue of «goods beyond the dowry " providing an overview of female non-dotal wealth in early modernity, also based on sources from Rome, Ago 1996. By the same author on issues of property in 17th-century Rome see also, Ago 1998. A few works have explored testamentary practices, for example on the fideicommissum see the studies collected in Chauvard - Bellavitis - Lanaro 2012. Other studies which more generally address the relationship between women and wealth from a long-term perspective are collected in Groppi 1996 and Calvi - Chabot 1998. 
conditions or procedures which were needed for women to be able to assert their property rights. ${ }^{9}$ The study further offers a comparative overview of the main developments in legislation concerning the legal capacity of women over the long term, charting the main developments during the period spanning the 13th to the 17 th centuries. ${ }^{10}$

Similarly, our scope here is not just to dwell on the nature of these assets. We will, more in general, tackle the question of how female goods were administered, and assess the role women played in managing patrimonies.

The studies collected here focus on a specific geographical area. Such a choice is not coincidental. North-central Italy is a multifarious but coherent context, especially for what concerns the issues which are being addressed. Scholarship has long established that developments in law and practice in this area largely followed a uniform path. It is in fact accepted as a given that from as early as the mid-12th century female property rights in the north-central Italian communes began to be progressively restricted, and ostensibly this process is directly linked to the dowry. Prior to these developments, the influence of Barbarian law led to the introduction of practices which granted substantial rights to married women over their husband's patrimony. The so-called quarta (the widow's right to a fourth part of her husband's belongings in areas influenced by Lombard law) and the tercia (the widow's right to a third part of her husband's belongings in areas influenced by Frankish law) established a sort of joint-property regime between spouses which had significant repercussions when alienating property - for example, in that the wife's consent was needed for the validation of such transfers. ${ }^{11}$

We can easily take the years 1141 and 1143 as starting points. In 1141, the first extant communal statute redacted in Pisa abolished the quarta with retroactive effect. ${ }^{12}$ Genoa followed suit. In 1143 , the consuls issued a decree which established that all married women living in the diocese of Genoa could no longer claim the tercia upon their

9. Feci 2004, p. 12.

10. Ibid., p. 29-64.

11. Bellomo 1961, p. 1-4. More in detail on the pre-communal period Vismara 1977; Feller 2002 and Bougard 2002.

12. For this and successive developments, Storti Storchi 1998, p. $72 \mathrm{ff}$. spouse's predecease. ${ }^{13}$ Similar norms were introduced in later years in other cities. ${ }^{14}$ The widow's right to part of her husband's patrimony - a right, which had undoubtedly given (especially aristocratic) women substantial authority within their families - was substituted by the dowry (provided by the bride's family) and by the counter-dowry (the groom's gift to his betrothed), both administered by the husband during marriage. ${ }^{15}$ The reasons at the heart of this dramatic change should perhaps be reassessed, or at least nuanced. Current scholarship still accepts the explanation given by Manlio Bellomo in his classical study Ricerche sui rapporti patrimoniali fra coniugi (1961). According to Bellomo, the shift to a dotal system is linked to the nascent communes. ${ }^{16}$ Understandably, increasing competition for power among the aristocratic families went hand in hand with the need to keep their estates within the male line. The urgency to consolidate their position and reinforce the agnatic line entailed that the aristocracy had to avoid at all costs the fragmentation of their estates and the passage of sizeable portions of wealth to widows who could, in case they remarried, even transfer their newly-acquired wealth to an antagonistic family.

Enhanced patrilineage came by installments. Following the rediscovery of Roman law, rules restricting the rights of females to acquire and manage their wealth autonomously were introduced progressively through the 13th to 15 th centuries (and beyond) with the successive redaction and amendment of municipal legal codes. Dowered daughters began to be excluded from their parents' inheritance in wills as early as from the late 12 th century. ${ }^{17}$ By the late 13th century the principle of the exclusio propter dotem (a concept which was further strengthened

13. Even the Genoese annals, which contain an illustration of two women extending their empty hands as if to underscore the importance of this development, report the issuing of this decree in the entry for 1143, Braccia 2001, p. 86; Bellomo 1970, p. 38.

14. On the so-called odium terciae/quartae see Bellomo 1961, p. $5 \mathrm{ff}$. On practices concerning the transfer of wealth to women through marriage before the 12th-century see in general Bougard - Feller - Le Jan 2002 and Vismara 1977; specifically on north-central Italy, Bougard 2002.

15. In general, on the passage to the dowry system in western Europe, see Hughes 1978.

16. Bellomo 1961, p. 5-13, to date remains the basic text.

17. Mayali 1987, p. 23, 35-36. 
when women began to be excluded from inheritance propter masculos) was enforced by statute in most cities across northern and central Italy. ${ }^{18}$ Largely overlooked by scholars, the rules of intestacy - which, in stark contrast with the principle of equity prescribed by the ius commune, ${ }^{19}$ bolstered the principle of agnatic precedence - introduced in municipal legislation in the same period are of fundamental importance in determining the extent to which women could gain access to additional wealth. ${ }^{20}$ Moreover, in some cities, statutes even regulated the management of non-dotal assets by means of specific laws. Such was the case, for example, of Verona, where by virtue of the statutes of 1276 the communal legislators established that all non-dotal goods of a wife had to be subject to the same rules as the dowry. ${ }^{21}$ In Ravenna, a similar norm was introduced much earlier, at the turn of the 13th century.22

Although these norms were introduced almost concurrently across northern and central Italy, past scholarly literature has mainly focused on the developments in, and differences between, two specific cities: Florence and Venice. As it is widely known, these two cities have been taken as paradigms on the one hand of bleak and grim conditions of married women (the former) and on the other of female agency (the latter). Christiane KlapischZuber's groundbreaking studies have elucidated the restrictions which were progressively imposed on Florentine women. ${ }^{23}$ Conversely, in his essays on Venetian society, Stanley Chojnacki has argued that legal developments actually gave leverage to Venetian women, who were able to display significant social and economic agency. ${ }^{24}$ These studies have had substantial influence in scholarly litera-

18. Niccolai 1940, p. $65 \mathrm{ff}$.

19. According to Justinianean law, intestate inheritances were to be distributed equally among direct descendants, regardless of gender. In order to leave all the heirs even, dowered women were supposed to collate their dowries before sharing out the inheritance, Kuehn 2017, p. 168-169.

20. Niccolai 1940, p. 65 ff. So far, very few studies have addressed the rules of intestacy in single cities. For Florence see Chabot 1998, 2011; Siena: Lumia-Ostinelli 2003; Bologna: Guiliodori 2005; Milan: Kuehn 2015; Venice: Bellavitis 1995; finally Genoa, Pisa, and Turin are discussed in this monographic issue.

21. Bellomo 1961, p. 139.

22. Ibid.

23. See the studies collected in Klapisch-Zuber 1985.

24. Mainly the studies collected in Chojnacki 2000. ture, but this sweeping view has been largely mitigated, adding complexity to the otherwise stereotypical image of the two cities. ${ }^{25}$ For what concerns Florence, scholars have underscored the importance of ambiguities in law which could provide women with some form of leeway. ${ }^{26}$ Chojnacki's stance, instead, has been criticized by Anna Bellavitis and Isabelle Chabot who have argued that Venetian men actually continued to exercise control over women. ${ }^{27}$

At any rate, between these two historiographical monoliths - Florence and Venice - which scholars have traditionally placed at the opposing ends of the spectrum, are an array of realities, small and large, each with their own set of rules and customs. Arguably, despite the substantially uniform intentions underlying the process which I have highlighted above, the legislative panorama of high and late medieval north-central Italy is of labyrinthine complexity. The fragmentation of the area into a plethora of self-governing communes, each with its own statute which - under the umbrella of the ius commune ${ }^{28}$ - was devised to suit the specificities and inclinations of each city, meant that while legislation was patrilineally-oriented, norms regulating the transmission of wealth to females and its management could present substantial variations from context to context. Not only this: differences could exist even in the same city. If we take for example the cases of Bergamo and Pavia, where Lombard law was abrogated only at the turn of the 15th century, we can observe references to the quarta even in late medieval documents. ${ }^{29}$ Ostensibly, these differences could determine increased or decreased possibilities for women to accrue and manage wealth beyond their dowries.

25. For an overview of the debate see Chabot 2006, p. 264-267.

26. Kuehn 1991, p. 1 ff.; Kuehn 2015, p. 406-407.

27. Bellavitis - Chabot 2005 .

28. Despite most of the restrictive measures ran counter to the prescription of the ius commune, finding ways and means to justify these deviations was a constant worry of medieval glossators. On the coexistence of ius commune and ius proprium, see Mayali 1987, p. $75 \mathrm{ff}$.

29. Storti Storchi 2010, p. 77-78. 
In the end however, the outcome of this process was ubiquitous: on the threshold of early modernity, all over north-central Italy, women were largely deprived of the right to manage their own property freely during marriage, ${ }^{30}$ and the chances for them to inherit substantial portions of their families' wealth were dramatically reduced. ${ }^{31}$ In this regard, (although the scholar has stressed that degree of female agency could vary) ${ }^{32}$ the maps charted by Simona Feci in her Pesci fuor d'acqua provide what is perhaps the most eloquent illustration of the changes in the legislative landscape of northern and central Italy. ${ }^{33}$

While it is certain that over the centuries women suffered severe cutbacks to their ability to acquire and manage wealth, the extent to which legal prescriptions were religiously observed must be called into question. Especially scholarly literature addressing consilia has shown that law was not always followed with absolute and uncompromising rigour. Complex and often contradictory laws provided good lawyers and other legal experts with paradoxes they could turn to the advantage (or disadvantage) of women and their families. ${ }^{34}$ Enhanced or diminished agency could therefore depend on the abilities and expertise of one's lawyers. Research in this direction, which at the moment is rather scant, could serve to further add complexity and nuance the impression of a rather uniform progression one gets when considering statutory law and other types of sources.

In the awareness that the question needs to be addressed further, the studies collected here are aimed at providing a set of comparative case studies which offer an initial insight into the multifarious (and yet to be charted) topic of female wealth and agency. Genoa and Pisa, the first cities to introduce a dotal system proper, are highly symbolic cases which largely fit within the more general picture. Conversely, the developments that can be observed in Turin, a small city by communal standards, are at variance with what was happening in other northern and central Italian cities. Early modern Florence, which has been the object of multiple scholarly works, is addressed through a littlestudied source - female account books - which provides us with a very specific and unique case study. Finally, the issue of how female property was conceived and managed in Jewish societies, will enable to ascertain the extent to which norms and practices that were followed by this religious minority conformed to the more general pattern evident in Christian society across northern and central Italy.

30. So much so that Bellomo has spoken of an "attrazione dei beni parafernali nella sfera normativa della dote ", a tendency, therefore, to assimilate dotal and non-dotal assets evident in both statutory law and practice almost everywhere in northern and central Italy, Bellomo 1961, p. 141.

31. Although dated, the study by Niccolai 1940, p. 65 ff., remains valid to gain a clear picture of the developments in legislation on intestacy. See also note 16 .

32. Feci 2004, p. 29-39.

33. Ibid., p. 63-64.

34. Some examples are provided in Kirshner 2015, p. 81-82. See also Kirshner - Pluss 1979. In this regard see also the comments by Grillo forthcoming. 


\section{Bibliography}

Ago 1996 = R. Ago, Oltre la dote: $i$ beni femminili, in Groppi 1996, p. 164-182.

Ago $1998=$ R. Ago, Universel/particulier : femmes et droits de propriété (Rome, XVII siècle), in Clio. Femmes, Genre, Histoire, 7, 1998.

Allegra $1993=\mathrm{L}$. Allegra, A model of Jewish devolution: Turin in the eighteenth century, in Jewish History, 7-2, 1993, p. 29-58.

Bellavitis 1995 = A. Bellavitis, La famiglia «cittadina» veneziana nel XVI secolo: dote e successione. Le leggi e le fonti, in Studi veneziani, 30, 1995, p. 55-68.

Bellavitis - Chabot $2005=$ A. Bellavitis, I. Chabot, A proposito di "Men and women in Renaissance Venice» di Stanley Chojnacki, in Quaderni Storici, 118-1, 2005, p. 203-238.

Bellomo $1961=\mathrm{M}$. Bellomo, Ricerche sui rapporti patrimoniali fra $i$ coniugi: contributo alla storia della famiglia medievale, Milan, 1961.

Bellomo $1970=$ M. Bellomo, La condizione giuridica della donna in Italia. Vicende antiche e moderne, Turin, 1970.

Bezzina forthcoming = D. Bezzina, Charting the "Extrados» (non-dotal goods) in Genoa and Liguria, (mid-Twelfth Thirteenth Centuries), in Journal of Medieval History, forthcoming.

Bougard 2002 = F. Bougard, Dot et douaire en Italie centro-septentrionale, VIII $-X I^{e}$ siècle. Un parcours documentaire, in Bougard - Feller - Le Jan 2002, p. 57-95.

Bougard - Feller - Le Jan 2002 = F. Bougard, L. Feller, R. Le Jan (eds.), Dots et douaires dans le Haut Moyen Âge, Rome, 2002 (Collection de l'École française de Rome, 295).

Braccia $2001=$ R. Braccia, "Uxor gaudet de morte mariti»: la donatio propter nuptias tra diritto comune e diritti locali, in Annali della Facoltà di Giurisprudenza di Genova, 30, 2000-2001, p. 84-94.

Calvi - Chabot $1998=$ G. Calvi, I. Chabot, La ricchezza delle donne. Diritti patrimoniali e poteri familiari in Italia (XIIIXIX secc.), Turin, 1998.

Chabot 1998 = I. Chabot, La loi du lignage. Notes sur le système successoral florentin (XIV $-X V^{e}, X V I I^{e}$ siècles), in Clio. Histoire, femmes et sociétés, 7, 1998, p. 51-72.

Chabot $2006=$ Richesses des femmes et parenté dans l'Italie de la Renaissance, in I. Chabot, J. Hayez, D. Lett (eds.), La famille, les femmes et le quotidien (XIVe-XVIII siècle). Textes offerts à Christiane Klapisch-Zuber, Paris, 2006, p. 263290.

Chabot 2011 = I. Chabot, La dette des familles. Femmes, lignage et patrimoine à Florence aux XIVe et XVe siècles, Rome, 2011 (Collection de l'École française de Rome, 445).

Chabot forthcoming = I. Chabot, Deux, trois, cent Italies. Réflexions pour une cartographie historique des systèmes dotaux (XII ${ }^{e}$-XVI $T^{e}$ siècles), in M.P. Mainoni, N.L. Barile (eds.), Two Italies compared. Civic tradition, trade networks, and family relationships between communal Italy and the Kingdom of Sicily, forthcoming.

Chauvard - Bellavitis - Lanaro 2012 = J.-F. Chauvard, A. Bellavitis, P. Lanaro (eds.), Fidéicommis. Procédés juridiques et pratiques sociales (Italie - Europe, Bas Moyen
Âge - XVIII e siècle), in MEFRIM, 124-2, 2012, p. 321 605.

Chojnacki $2000=$ S. Chojnacki, Women and men in Renaissance Venice. Twelve essays on patrician society, Baltimore-London, 2000.

Di Carpegna Falconieri $1995=$ T. Di Carpegna Falconieri, Sposarsi a Roma. Alcuni aspetti del matrimonio tra VIII e XIII secolo, in Ricerche Storiche, 25-1, 1995, p. 3-33.

Esposito 2013 = A. Esposito, Disegualglianze economiche e cittadinanza: il problema della dote, in MEFRM, 125-2, 2013.

Feci 2004 = S. Feci, Pesci fuor d'acqua. Donne a Roma in età moderna: diritti e patrimoni, Rome, 2004.

Feller 2002 = L. Feller, "Morgengabe», dot, «tertia» : rapport introductif, in Bougard - Feller - Le Jan 2002, p. 1-25.

Gasperoni 2015 = M. Gasperoni, La misura della dote. Alcuni riflessioni sulla storia della famiglia ebraica nello Stato della Chiesa in età moderna, in L. Graziani Secchieri (ed.), Vicino al focolare e oltre. Spazi pubblici e privati, fisici e virtuali della donna ebrea in Italia (secc. $X V$ - XX), Florence, 2015, p. 175-216.

Giuliodori 2005 = S. Giuliodori, "De rebus uxoris». Dote e successione negli statuti bolognesi (1250-1454), in Archivio storico italiano, 163-4, 2005, p. 651-679.

Grillo forthcoming = P. Grillo, Conclusions: many centuries, many Italies, in M.P. Mainoni, N.L. Barile (eds.), Two Italies compared. Civic tradition, trade networks, and family relationships between communal Italy and the Kingdom of Sicily, forthcoming.

Groppi 1996 = A. Groppi (ed.), Storia delle donne in Italia, II. Il lavoro delle donne, Rome-Bari, 1996.

Hughes 1978 = D.O. Hughes, From brideprice to dowry in Mediterranean Europe, in Journal of Family History, 3, 1998, p. 262-296.

Kirshner 2015 = J. Kirshner, Marriage, dowry, citizenship in Late Medieval and Renaissance Italy, Toronto, 2015, p. 74-93.

Kirshner - Molho 1978 = J. Kirshner, A. Molho, The dowry fund and the marriage market in early Quattrocento Florence, in The journal of modern history, 50-3, 1978, p. 403-438.

Kirshner-Pluss $1979=$ J. Kirshner, J. Pluss, Two fourteenthcentury opinions on dowries, "paraphernalia" and nondotal goods, in Bulletin of medieval canon law, 9, 1979, p. 65-77.

Klapisch-Zuber 1985 = C. Klapisch-Zuber, The Griselda complex: dowry and marriage gifts in the Quattrocento, in Women, family and ritual in Renaissance Italy, ChicagoLondon, 1985, p. 213-246.

Kuehn 1991 = T. Kuehn, Law, family and women. Toward an anthropology of Renaissance Italy, Chicago, 1991.

Kuehn 2015 = T. Kuehn, Gender and law in Milan, in A. Gamberini (ed.), A companion to late medieval and early modern Milan. The distinctive features of an Italian state, Leiden, 2015, p. 406-431.

Kuehn 2017 = T. Kuehn, Family and gender in Renaissance Italy, 1300-1600, Cambridge-New York, 2017. 
Lanaro - Varanini 2009 = P. Lanaro, G.M. Varanini, Funzioni economiche della dote nell'Italia centro-settentrionale (tardo medioevo/inizi età moderna), in S. Cavaciocchi (ed.), La famiglia nell'economia europea, secc. XIII-XVIII, Istituto internazionale di storia economica F. Datini, Atti della "Quarantesima settimana di studi», 6-10 aprile 2008, Florence, 2009, p. 81-102.

Lumia-Ostinelli 2003 = G. Lumia-Ostinelli, "Ut cippus domus magis conservetur». La successione a Siena tra statuti e testamenti (secoli XII-XVII), in Archivio storico italiano, 161-1 (595), 2003, p. 3-51.

Mayali 1987 = L. Mayali, Droit savant et coutumes: l'exclusion des filles dotées, $X I I^{e}-X V^{e}$ siècles, Frankfurt am Main, 1987.

Niccolai 1940 = F. Niccolai, La formazione del diritto successorio negli statuti comunali del territorio lombardo-tosco, Milan, 1940.
Storti Storchi $1998=$ C. Storti Storchi, Intorno ai Costituti pisani della legge e dell'uso (secolo XII), Naples, 1998.

Storti Storchi 2012 = C. Storti Storchi, La condizione giuridica delle donne della famiglia nelle strategie testamentarie di Alberico da Rosciate (1345-1360), in M. Davide (ed.), La condizione giuridica delle donne nel medioevo, Convegno di studio, Trieste, 23 novembre 2010, Trieste, 2012, p. 5393.

Vismara $1977=$ G. Vismara, I rapporti patrimoniali tra coniugi nell'alto medioevo, in Il matrimonio nella società medievale, Spoleto, 1977 (Settimane di studio del centro italiano di studi sull'Alto medioevo, 24), p. 633-691.

Zucca Micheletto 2011 = The relevance of dowry: dowry alienation, family economy and livelihood strategies of couples in Turin in the eighteenth century, in Annales de démographie historique, 121-1, 2011, p. 161-186. 
